\title{
WOMEN EMPOWERMENT THROUGH MICRO FINANCE
}

\author{
Marie Wilson . $\mathbf{N}^{1}$, Regeena Wilson ${ }^{2}$, Thangavel . $\mathbf{N}^{3}$ \\ ${ }^{1,2}$ Jeppiaar Engineering College, Jeppiaar Nagar, Rajiv Gandhi Road, Chennai, India \\ ${ }^{3}$ Jeppiaar Engineering College, Rajiv Gandhi Road, Chennai, India \\ E-mail : 'office@jeppiaarcollege.org
}

\section{Abstract}

It was expected that women will equally benefit along with men. This has been belied by actual development. The ninth plan document recognizes that in spite of development measures and constitutional legal guarantees- women have lagged behind in almost all sectors. In India, the emergence of liberalization and globalization in early 1990's aggravated the problem of women workers in unorganized sectors from bad to worse as most of the women who were engaged in various self employment activities have lost their livelihood. Microfinance is emerging as a powerful instrument for poverty alleviation in the new economy. In India, Microfinance scene is dominated by Self Help Group (SHGs)-Bank Linkage Programme as a cost effective mechanism for providing financial services to the "Unreached Poor" which has been successful not only in meeting financial needs of the rural poor women but also strengthen collective self help capacities of the poor ,leading to their empowerment. Rapid progress in SHG formation has now turned into an empowerment movement among women across the country. This paper puts forward how micro finance has received extensive recognition as a strategy for economic empowerment of women. This paper seeks to examine the impact of Micro finance with respect to poverty alleviation and socioeconomic empowerment of rural women. An effort is also made to suggest the ways to increase women empowerment.

Key words: Empowerment, Self Help Group (SHG), Micro-Finance

\section{INTRODUCTION}

Empowerment implies expansion of assets and capabilities of people to influence control and hold accountable institution that affects their lives (World Bank Resource Book).Empowerment is the process of enabling or authorizing an individual to think, behave, take action and control work in an autonomous way. It is the state of feelings of self-empowered to take control of one's own destiny. It includes both controls over resources (Physical, Human, Intellectual and Financial) and over ideology (Belief, values and attitudes) (Batliwala, 1994).

Empowerment can be viewed as a means of creating a social environment in which one can take decisions and make choice either individually or collectively for social transformation. It strength innate ability by way of acquiring knowledge power and experience.

Empowerment is a multi-dimensional social process that helps people gain control over their own lives communities and in their society, by acting on issues that they define as important. Empowerment occurs within sociological psychological economic spheres and at various levels, such as individual, group and community and challenges our assumptions about status quo, asymmetrical power relationship and social dynamics. Empowering women puts the spotlight on education and employment which are an essential element to sustainable development.

\section{EMPOWERMENT: FOCUS ON POOR WOMEN}

In India, the trickle down effects of macroeconomic policies have failed to resolve the problem of gender inequality. Women have been the vulnerable section of society and constitute a sizeable segment of the povertystruck population. Women face gender specific barriers to access education health, employment etc. Micro finance deals with women below the poverty line. Micro loans are available solely and entirely to this target group of women. There are several reason for this: Among the poor , the poor women are most disadvantaged -they are characterized by lack of education and access of resources, both of which is required to help them work their way out of poverty and for upward economic and social mobility. The problem is more acute for women in countries like India, despite the fact that women's labour makes a critical contribution to the economy. This is due to the low social status and lack of access to key resources. Evidence shows that groups of women are better customers than men, the better managers of resources. If loans are routed through women benefits of loans are spread wider among the household.

Since women's empowerment is the key to socio economic development of the community; bringing women into the mainstream of national development has been a major concern of government. The ministry of rural development has special components for women in its programmes. Funds are earmarked as "Women's component" to ensure flow of adequate resources for the same. Besides Swarnagayanti Grameen Swarazgar 
Yojona (SGSY), Ministry of Rural Development is implementing other scheme having women's component .They are the Indira Awas Yojona (IAJ), National Social Assistance Programme (NSAP), Restructured Rural Sanitation Programme, Accelerated Rural Water Supply programme (ARWSP) the (erstwhile) Integrated Rural Development Programme (IRDP), the (erstwhile) Development of Women and Children in Rural Areas (DWCRA) and the Jowahar Rozgar Yojana (JRY).

\section{CONCEPT AND FEATURES OF MICRO FINANCE}

The term micro finance is of recent origin and is commonly used in addressing issues related to poverty alleviation, financial support to micro entrepreneurs, gender development etc. There is, however, no statutory definition of micro finance. The taskforce on supportitative policy and Regulatory Framework for Microfinance has defined microfinance as "Provision of thrift, credit and other financial services and products of very small amounts to the poor in rural, semi-urban or urban areas for enabling them to raise their income levels and improve living standards". The term "Micro" literally means "small". But the task force has not defined any amount. However as per Micro Credit Special Cell of the Reserve Bank Of India , the borrowed amounts up to the limit of Rs.25000/could be considered as micro credit products and this amount could be gradually increased up to Rs.40000/over a period of time which roughly equals to $\$ 500-a$ standard for South Asia as per international perceptions.

The term micro finance sometimes is used interchangeably with the term micro credit. However while micro credit refers to purveyance of loans in small quantities, the term microfinance has a broader meaning covering in its ambit other financial services like saving, insurance etc. as well.

The mantra "Microfinance" is banking through groups. The essential features of the approach are to provide financial services through the groups of individuals, formed either in joint liability or co-obligation mode. The other dimensions of the microfinance approach are:

$\begin{array}{ll}\text { 29y } & \text { Savings/Thrift precedes credit } \\ \text { 29y } & \text { Credit is linked with savings/thrift } \\ \text { थy } & \text { Absence of subsidies } \\ \text { 29y } & \begin{array}{l}\text { Group plays an important role in credit } \\ \text { appraisal, monitoring and recovery. }\end{array}\end{array}$

\section{Basically groups can be of two types:}

Self Help Groups (SHGs): The group in this case does financial intermediation on behalf of the formal institution. This is the predominant model followed in India.

Grameen Groups: In this model, financial assistance is provided to the individual in a group by the formal institution on the strength of group's assurance. In other words, individual loans are provided on the strength of joint liability/co obligation. This microfinance model was initiated by Bangladesh Grameen Bank and is being used by some of the Micro Finance Institutions (MFIs) in our country.

\section{WOMEN'S EMPOWERMENT AND MICRO FINANCE: DIFFERENT PARADIGMS}

Concern with women's access to credit and assumptions about contributions to women's empowerment are not new. From the early 1970s women's movements in a number of countries became increasingly interested in the degree to which women were able to access poverty-focused credit programmes and credit cooperatives. In India organizations like Self- Employed Women's Association (SEWA) among others with origins and affiliations in the Indian labour and women's movements identified credit as a major constraint in their work with informal sector women workers.

The problem of women's access to credit was given particular emphasis at the first International Women's Conference in Mexico in 1975 as part of the emerging awareness of the importance of women's productive role both for national economies, and for women's rights. This led to the setting up of the Women's World Banking network and production of manuals for women's credit provision. Other women's organizations world-wide set up credit and savings components both as a way of increasing women's incomes and bringing women together to address wider gender issues. From the mid-1980s there was a mushrooming of donor, government and NGOsponsored credit programmes in the wake of the 1985 Nairobi women's conference (Mayoux, 1995a).

The 1980s and 1990s also saw development and rapid expansion of large minimalist poverty-targeted micro-finance institutions and networks like Grameen Bank, ACCION and Finca among others. In these organizations and others evidence of significantly higher female repayment rates led to increasing emphasis on targeting women as an efficiency strategy to increase credit recovery. A number of donors also saw femaletargeted financially-sustainable micro-finance as a means of marrying internal demands for increased efficiency because of declining budgets with demands of the increasingly vocal gender lobbies.

The trend was further reinforced by the Micro Credit 
Summit Campaign starting in 1997 which had 'reaching and empowering women' as its second key goal after poverty reduction (RESULTS 1997). Micro-finance for women has recently been seen as a key strategy in meeting not only Millennium Goal 3 on gender equality, but also poverty Reduction, Health, HIVIAIDS and other goals.

\section{FEMINIST EMPOWERMENT PARADIGM}

The feminist empowerment paradigm did not originate as a Northern imposition, but is firmly rooted in the development of some of the earliest micro-finance programmes in the South, including SEWA in India. It currently underlies the gender policies of many NGOs and the perspectives of some of the consultants and researchers looking at gender impact of micro-finance programmes (e.g. Chen 1996, Johnson, 1997).

Here the underlying concerns are gender equality and women's human rights. Women's empowerment is seen as an integral and inseparable part of a wider process of social transformation. The main target group is poor women and women capable of providing alternative female role models for change. Increasing attention has also been paid to men's role in challenging gender inequality.

Micro-finance is promoted as an entry point in the context of a wider strategy for women's economic and socio-political empowerment which focuses on gender awareness and feminist organization. As developed by Chen in her proposals for a sub sector approach to micro credit, based partly on SEWA's strategy and promoted by UNIFEM, microfinance must be:

Based on participatory principles to build up incremental knowledge of industries and enable women to develop their strategies for change (Chen, 1996). Economic empowerment is however defined in more than individualist terms to include issues such as property rights, changes intra-household relations and transformation of the macro-economic context. Many organizations go further than interventions at the industry level to include gender-specific strategies for social and political empowerment. Some programmes have developed very effective means for integrating gender awareness into programmes and for organizing women and men to challenge and change gender discrimination. Some also have legal rights support for women and engage in gender advocacy. These interventions to increase social and political empowerment are seen as essential prerequisites for economic empowerment.

\section{A. Poverty Reduction Paradigm}

The poverty alleviation paradigm underlies many
NGO integrated poverty-targeted community development programmes. Poverty alleviation here is defined in broader terms than market incomes to encompass increasing capacities and choices and decreasing the vulnerability of poor people.

The main focus of programmes as a whole is on developing sustainable livelihoods, community development and social service provision like literacy, healthcare and infrastructure development. There is not only a concern with reaching the poor, but also the poorest.

Here gender lobbies have argued for targeting women because of higher levels of female poverty and women's responsibility for household well-being. However although gender inequality is recognized as an issue, the focus is on assistance to households and there is a tendency to see gender issues as cultural and hence not subject to outside intervention.

The assumption is that increasing women's access to micro-finance will enable women to make a greater contribution to household income and this, together with other interventions to increase household well-being, will translate into improved well-being for women and enable women to bring about wider changes in gender inequality.

\section{B. Financial Sustainability Paradigm}

The financial self-sustainability paradigm (also referred to as the financial systems approach or sustainability approach) underlies the models of microfinance promoted since the mid-1990s by most donor agencies and the Best Practice guidelines promoted in publications by USAID, World Bank, UNDP and CGAP.

The ultimate aim is large programmes which are profitable and fully self-supporting in competition with other private sector banking institutions and able to raise funds from international financial markets rather than relying on funds from development agencies. The main target group, despite claims to reach the poorest, is the 'bankable poor': small entrepreneurs and farmers. This emphasis on financial sustainability is seen as necessary to create institutions which reach significant numbers of poor people in the context of declining aid budgets and opposition to welfare and redistribution in macro-economic policy.

Policy discussions have focused particularly on setting of interest rates to cover costs, separation of microfinance from other interventions to enable separate accounting and programme expansion to increase outreach and economies of scale, reduction of transaction costs and ways of using groups to decrease costs of delivery. Recent guidelines for CGAP funding and best 
practice focus on production of a 'financial sustainability index' which charts progress of programmes in covering costs from incomes.

Within this paradigm gender lobbies have been able to argue for targeting women on the grounds of high female repayment rates and the need to stimulate women's economic activity as a hitherto underutilized resource for economic growth. They have had some success in ensuring that considerations of female targeting are integrated into conditions of micro-finance delivery and programme evaluation.

Alongside this focus on female targeting, the term 'empowerment' is frequently used in promotional literature. Definitions of empowerment are in individualist terms with the ultimate aim being the expansion of individual choice or capacity for Self-reliance. It is assumed that increasing women's access to microfinance services will in itself lead to individual economic empowerment through enabling women's decisions about savings and credit use, enabling women to set up microenterprise, increasing incomes under their control. It is then assumed that this increased economic empowerment will lead to increased well-being of women and also to social and political empowerment.

These paradigms do not correspond systematically to any one organizational model of micro-finance. Microfinance providers with the same organizational form e.g. village bank, Grameen model or cooperative model may have very different gender policies and/or emphases and strategies for poverty alleviation. The three paradigms represent different 'discourses' each with its own relatively consistent internal logic in relating aims to policies, based on different underlying understandings of development. They are not only different, but often seen as 'incompatible discourses' in uneasy tension and with continually contested degrees of dominance. In many programmes and donor agencies there is considerable disagreement, lack of communication and/or personal animosity and promoted by different stakeholders within organizations between staff involved in micro-finance (generally firm followers of financial self-sustainability), staff concerned with human development (generally with more sympathy for the poverty alleviation paradigm and emphasizing participation and integrated development) gender lobbies (generally incorporating at least some elements of the feminist empowerment paradigm

\section{Micro Finance Instrument For Women's Empowerment}

Micro Finance is emerging as a powerful instrument for poverty alleviation in the new economy. In India, micro finance scene is dominated by Self Help Groups (SHGs) Bank Linkage Programme, aimed at providing a cost effective mechanism for providing financial services to the "unreached poor". Based on the philosophy of peer pressure and group savings as collateral substitute , the SHG programme has been successful in not only in meeting peculiar needs of the rural poor, but also in strengthening collective self-help capacities of the poor at the local level, leading to their empowerment.

Micro Finance for the poor and women has received extensive recognition as a strategy for poverty reduction and for economic empowerment. Increasingly in the last five years, there is questioning of whether micro credit is most effective approach to economic empowerment of poorest and, among them, women in particular. Development practitioners in India and developing countries often argue that the exaggerated focus on micro finance as a solution for the poor has led to neglect by the state and public institutions in addressing employment and livelihood needs of the poor.

Credit for empowerment is about organizing people, particularly around credit and building capacities to manage money. The focus is on getting the poor to mobilize their own funds, building their capacities and empowering them to leverage external credit. Perception women is that learning to manage money and rotate funds builds women's capacities and confidence to intervene in local governance beyond the limited goals of ensuring access to credit. Further, it combines the goals of financial sustainability with that of creating community owned institutions.

Before 1990's, credit schemes for rural women were almost negligible. The concept of women's credit was born on the insistence by women oriented studies that highlighted the discrimination and struggle of women in having the access of credit. However, there is a perceptible gap in financing genuine credit needs of the poor especially women in the rural sector.

There are certain misconception about the poor people that they need loan at subsidized rate of interest on soft terms, they lack education, skill, capacity to save, credit worthiness and therefore are not bankable. Nevertheless, the experience of several SHGs reveals that rural poor are actually efficient managers of credit and finance. Availability of timely and adequate credit is essential for them to undertake any economic activity rather than credit subsidy.

The Government measures have attempted to help the poor by implementing different poverty alleviation programmes but with little success. Since most of them are target based involving lengthy procedures for loan 
disbursement, high transaction costs, and lack of supervision and monitoring. Since the credit requirements of the rural poor cannot be adopted on project lending app roach as it is in the case of organized sector, there emerged the need for an informal credit supply through SHGs. The rural poor with the assistance from NGOs have demonstrated their potential for self help to secure economic and financial strength. Various case studies show that there is a positive correlation between credit availability and women's empowerment.

\section{PROBLEMS AND CHALLENGES}

Surveys have shown that many elements contribute to make it more Difficult for women empowerment through micro businesses. These elements are:

2y Lack of knowledge of the market and potential profitability, thus making the choice of business difficult.

2iI Inadequate book-keeping.

2iy Employment of too many relatives which increases social pressure to share benefits.

2̇y Setting prices arbitrarily.

2̇y Lack of capital.

2iv High interest rates.

21y Inventory and inflation accounting is never undertaken.

2y Credit policies that can gradually ruin their business (many customers cannot pay cash; on the other hand, suppliers are very harsh towards women).

29y Burden of meeting.

2y New Pressures

2y Reinforcement of traditional gender roles.

\section{A. Challenging Economic Empowerment}

However impact on incomes is widely variable. Studies which consider income levels find that for the majority of borrowers income increases are small, and in some cases negative. All the evidence suggests that most women invest in existing activities which are low profit and insecure and/or in their husband's activities. In many programmes and contexts it is only in a minority of cases that women can develop lucrative activities of their own through credit and savings alone.

It is clear that women's choices about activity and their ability to increase incomes are seriously constrained by gender inequalities in access to other resources for investment, responsibility for household subsistence expenditure, lack of time because of unpaid domestic work and low levels of mobility, constraints on sexuality and sexual violence which limit access to markets in many cultures.

These gender constraints are in addition to market constraints on expansion of the informal sector and resource and skill constraints on the ability of poor men as well as women to move up from survival activities to expanding businesses. There are signs, particularly in some urban markets like Harare and Lusaka that the rapid expansion of micro-finance programmes may be contributing to market saturation in 'female' activities and hence declining profits.

\section{B. Challenging Well Being And Intra Household Relation}

There have undoubtedly been women whose status in the household has improved, particularly where they have become successful entrepreneurs. Even where income impacts have been small, or men have used the loan, the fact that micro-finance programmes have thought women worth targeting and women bring an asset into the household may give some women more negotiating power.

Savings provide women with a means of building up an asset base. Women themselves also often value the opportunity to be seen to be making a greater contribution to household well-being giving them greater confidence and sense of self-worth.

However women's contribution to increased income going into households does not ensure that women necessarily benefit or that there is any challenge to gender inequalities within the household. Women's expenditure patterns may replicate rather than counter gender inequalities and continue to disadvantage girls. Without substitute care for small children, the elderly and disabled, and provision of services to reduce domestic work many programmes reported adverse effects of women's outside work on children and the elderly. Daughters in particular may be withdrawn from school to assist their mothers.

Although in some contexts women may be seeking to increase their influence within joint decision-making processes rather than independent control over income (Kabeer 1998), neither of these outcomes can be assumed. Women's perceptions of value and self-worth are not necessarily translated into actual well-being benefits or change in gender relations in the household 
(Sen 1990, Kandiyoti 1999). Worryingly, in response to women's increased (but still low) incomes evidence indicates that men may be withdrawing more of their own contribution for their own luxury expenditure. Men are often very enthusiastic about women's credit programmes, and other income generation out programmes, for this reason because their wives no longer 'nag' them for money (Mayoux 1999).

Small increases in access to income and influence may therefore be at the cost of heavier work loads, increased stress and women's health. Although in many cases women's increased contribution to household wellbeing has improved domestic relations, in other cases it intensifies tensions.

\section{Challenging Social And Political Empowerment}

There have been positive changes in household and community perceptions of women's productive role, as well as changes at the individual level. In societies like Sudan and Bangladesh where women's role has been very circumscribed and women previously had little opportunity to meet women outside their immediate family there have sometimes been significant changes. It is likely that changes at the individual, household and community levels are interlinked and that individual women who gain respect in their households then act as role models for others leading to a wider process of change in community perceptions and male willingness to accept change (Lakshman, 1996).

Micro-finance has also been strategically used by some NGOs as an entry point for wider social and political mobilization of women around gender issues. For example SEWA in India, CODEC in Bangladesh and CIPCRE in Cameroon, indicate the potential of microfinance to form a basis for organization against other issues like domestic violence, male alcohol abuse and dowry.

However there is no necessary link between women's individual economic empowerment and/or participation in micro-finance groups and social and political empowerment. These changes are not an automatic consequence of microfinance. As noted above, women's increased productive role has also often had it costs.

The evidence therefore indicates that contributions of micro-finance per se to women's empowerment cannot be assumed and current complacency in this regard is misplaced. In many cases contextual constraints at all levels have prevented women from accessing programmes, increasing or controlling incomes or challenging subordination. Where women are not able to significantly increase incomes under their control or negotiate changes in intra-household and community gender inequalities, women may become dependent on loans to continue in very low-paid occupations with heavier workloads and enjoying little benefit.

For some women micro-finance has been positively disempowering, as indicated by some of the cases shown above which are far from isolated examples:

2iy Credit (i.e. debt) may lead to severe impoverishment, abandonment and put serious strains on networks with other women.

29y Pressure to save may mean women forgoing their own necessary consumption.

2y The contribution of micro-finance alone appears to be most limited for the poorest and most disadvantaged women.

\section{CONCLUSIONS AND SUGGESTIONS}

Numerous traditional and informal system of credit that was already in existence before micro finance came into vogue. Viability of micro finance needs to be understood from a dimension that is far broader- in looking at its long-term aspects too .very little attention has been given to empowerment questions or ways in which both empowerment and sustainability aims may be accommodated. Failure to take into account impact on income also has potentially adverse implications for both repayment and outreach, and hence also for financial sustainability. An effort is made here to present some of these aspects to complete the picture.

A conclusion that emerges from this account is that micro finance can contribute to solving the problems of inadequate housing and urban services as an integral part of poverty alleviation programmes. The challenge lies in finding the level of flexibility in the credit instrument that could make it match the multiple credit requirements of the low income borrower without imposing unbearably high cost of monitoring its end use upon the lenders. A promising solution is to provide multipurpose lone or composite credit for income generation, housing improvement and consumption support. Consumption loan is found to be especially important during the gestation period between commencing a new economic activity and deriving positive income. Careful research on demand for financing and savings behavior of the potential borrowers and their participation in determining the mix of multi-purpose loans are essential in making the concept work.

The organizations involved in micro credit initiatives should take account of the fact that: 
2iy Credit is important for development but cannot by itself enable very poor women to overcome their poverty.

2́1

Making credit available to women does not automatically mean they have control over its use and over any income they might generate from micro enterprises.

2y In situations of chronic poverty it is more important to provide saving services than to offer credit.

27. A useful indicator of the tangible impact of micro credit schemes is the number of additional proposals and demands presented by local villagers to public authorities.

Nevertheless ensuring that the micro-finance sector continues to move forward in relation to gender equality and women's empowerment will require a long-term strategic process of the same order as the one in relation to poverty if gender is not to continue to 'evaporate' in a combination of complacency and resistance within donor agencies and the micro-finance sector. This will involve:

2y Ongoing exchange of experience and innovation between practitioners

2y Constant awareness and questioning of 'bad practice'

2y Bringing together the different players in the sector to develop coherent policies and for gender advocacy.

India is the country where a collaborative model between banks, NGOs, MFIs and Women's organizations is furthest advanced. It therefore serves as a good starting point to look at what we know so far about 'Best Practice' in relation to micro-finance for women's empowerment and how different institutions can work together.

It is clear that gender strategies in micro finance need to look beyond just increasing women's access to savings and credit and organizing self help groups to look strategically at how programmes can actively promote gender equality and women's empowerment. Moreover the focus should be on developing a diversified micro finance sector where different type of organizations, NGO, MFls and formal sector banks all should have gender policies adapted to the needs of their particular target groups/institutional roles and capacities and collaborate and work together to make a significant contribution to gender equality and pro-poor development.

\section{REFERENCES}

[1] Fisher, Thomas and M.S. Sriram ed., 2002, Beyond Micro-credit: Putting Development Back into Microfinance, New Delhi: Vistaar Publications; Oxford: Oxfam.

[2] Harper, Malcolm, 2002, "Promotion of Self Help Groups under the SHG Bank Linkage Program in India", Paper presented at the Seminar on SHGbank Linkage Programme at New Delhi, November 25-26, 2002.

[3] Kabeer N (2001), "Conflicts Over Credit: Reevaluation the Empowerment Potential of Loans to Women in Rural Bangladesh": World Development, Vol.29, No.1.

[4] Mayoux, L. 1998a. Women's Empowerment and Micro-finance programmes: Approaches, Evidence and Ways Forward. The Open University Working Paper No 41.

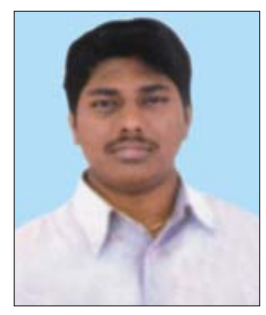

[5]Ackerley, B. (1995). Testing the Tools of Development: Credit Programmes, Loan Involvement and Women's Empowerment. World Development, 26(3), 56-68.

Er. Marie Wilson Director - Jeppiaar Engineering College, Chennai He has co-coordinated 2 AICTE sponsored short time training programmes. He has published 2 papers in international journals and presented 3 papers in international conferences.

Er. Regeena Wilson Director Jeppiaar Engineering College, Chennai She has presented 3 papers in international conferences and has published papers in 2 international journals. Her areas of interest are Global Strategic Management and Services Management. 